\title{
Population Structure of the Freshwater Crab Potamon algeriense (Bott, 1967) Inhabiting Oued Zegzel, (Northeast of Morocco)
}

\author{
Soufiane Fadlaoui (iD) and Mohammed Melhaoui \\ Mohamed First University, Faculty of Sciences, Department of Biology, Laboratory of Water, \\ Environment and Sustainable Development, Oujda, P. B. 717, Morocco
}

Correspondence should be addressed to Soufiane Fadlaoui; soufiane.fadlaoui@gmail.com

Received 5 July 2019; Revised 23 November 2019; Accepted 3 December 2019; Published 20 December 2019

Academic Editor: Daniel I. Rubenstein

Copyright (C) 2019 Soufiane Fadlaoui and Mohammed Melhaoui. This is an open access article distributed under the Creative Commons Attribution License, which permits unrestricted use, distribution, and reproduction in any medium, provided the original work is properly cited.

\begin{abstract}
This is the first study to determine the population structure of the freshwater crab Potamon algeriense in Oued Zegzel, a mountain stream in the northeast of Morocco. Monthly collections were carried out by hand, from October 2017 to September 2018. A total of 669 individuals, 378 males and 291 females, were captured, measured, marked, and released. Due to their extremely cryptic behavior during egg incubation, few ovigerous females were caught during the entire sampling period. The average size of males $(28.98 \pm 10.78 \mathrm{~mm} \mathrm{CW})$ is significantly larger than that of the females $(28.62 \pm 8.48 \mathrm{~mm} \mathrm{CW})$. Significant deviation from $1: 1 \mathrm{sex}$ ratio during the study period was recorded, and the size distribution of the sampled population presented an abnormal distribution where specimens over 31 and under $25 \mathrm{~mm}$ CW were often males, whereas females were represented more in the 26-30 $\mathrm{mm}$ CW range.
\end{abstract}

\section{Introduction}

Compared with marine crabs, freshwater crabs are considered to have rather low dispersal ability and high rates of endemism [1]. They can cross longer terrestrial distances away from their aquatic habitat under humid conditions $[2,3]$. Additionally, their philopatry is increased by the absence of marine planktonic larvae and by their brood care behavior. Consequently, the juveniles are forced to stay in the parental habitat [3,4]. Furthermore, freshwater crabs are characterized by their low fecundity with small numbers of large eggs, brood protection, and shorter larval development [5].

Most brachyurans living in freshwater belong to the superfamily Potamoidea, which includes four families, namely, Pseudothelphusidae; Potamidae; Potamonautidae; and Gecarcinucidae.

The Potamidae is the largest of all freshwater crab families and comprises 95 genera, and more than 505 species are distributed throughout the southern Palaearctic and oriental zoogeographical regions from Morocco to as far east as Japan, and as far south as Indonesia [6-8]. This family includes many studied species, for example, the subspecies Potamon potamios palestinensis found in Palestine is widely represented in aquatic habitats throughout most of the country, comprising the arid Negev, and its distribution extends as far as the northernmost corner of Sinai [9]. The animals are active all year round and are prevalently nocturnal. In its feeding habits, this species behaves as a generalist, actively preying on frogs, fishes, and various invertebrates [10].

Besides this subspecies, we found the freshwater crab Potamon fluviatile, which its distribution covers, parts of many countries especially, in mainland Italy and on the Balkan Peninsula from Dalmatia to the Axios river in Greece [11]. Its occurrence also comprises several islands, including Sicily, Malta, and Gozo, the Ionian Islands, Aegean Islands, Sporades, and Andros in the Cyclades [12]. Small individuals shelter under stones, while adult ones inhabit burrows. The depth of burrows could reach more than $80 \mathrm{~cm}$ and likely serve to protect the crabs from extreme cold [13].

The only Maghrebian representative of this family is Potamon algeriense (Bott, 1967), whose members are 
reported around the Mediterranean, the Middle East, and the Himalayas. In fact, $P$. algeriense in northern Africa represents the westernmost extension of this family. The species is found only in three countries: Morocco, Algeria, and Tunisia [14]. In Morocco, the species has been reported from the North in the watershed of the Oued Laou near Chefchaouen from the Northeast watershed of Moulouya and from the Middle Atlas in the Oued Oum Rbia watershed near Khenifra.

Potamon algeriense is usually found under stones in the shallow water of the temperate rivers of Maghreb and in seasonally arid freshwater bodies where crabs are adapted to be semiterrestrial and can dig burrows that can reach $50 \mathrm{~cm}$ depth looking for water and humidity [15]. Potamon algeriense is an omnivore and opportunistic species, and its diet comprises invertebrates, tree leaves, fish, and cadavers. Cannibalism is also present between unequal individuals (large crabs devour small ones).

Despite the wide distribution of $P$. algeriense, its populations are discontinuous and highly fragmented, and there is a cause for taking into consideration the future stability of a number of its isolated subpopulations. Even though this species is included in the IUCN red list as least concern species [16], the crab populations may nevertheless be threatened in the future due to rapid anthropogenic changes affecting their habitats such as water diversion and pollution. As a consequence, $P$. algeriense populations might face the threat of extirpation soon, especially those existing in the proximity of human agglomerations.

The available information about the population biology of freshwater crabs is very scarce [13, 17-19], and Potamon algeriense makes no exception since all information about this species is nonupdated, and studies treat only its geographic distribution and taxonomic status [16].

The present manuscript aims to describe for the first time the population structure of the freshwater $P$. algeriense from Oued Zegzel, a mountain stream in the Northeast of Morocco.

\section{Materials and Methods}

Crabs were collected monthly over one year (October 2017 to September 2018) from Oued Zegzel ( $34^{\circ} 50^{\prime} 29.4^{\prime \prime} \mathrm{N} 2^{\circ} 21^{\prime}$ $\left.19.8^{\prime \prime} \mathrm{W}\right)$, a tributary of the lower Moulouya river in the northeast of Morocco (Figure 1), by excavating burrows and searching under blocks.

Crabs were caught manually by plunging an arm into the burrow, and their Carapace Widths (CW) were then measured from the widest part to the nearest $0.01 \mathrm{~mm}$ using a Vernier caliper (Figure 2). They were then marked by the ablation of the dactylus of the walking leg, without handicapping the individual (to avoid remeasuring), and then they were released.

The depth of the burrow can reach more than $50 \mathrm{~cm}$ (Figure 3); it was not always possible to catch the crabs before they escaped to the greater depths. Consequently, the individuals assessed here represent a haphazard sample.

For all crabs, the sex determination was based on their abdominal morphology (considerably wider in females than in males) (Figure 4) and the number of pleopods. The presence of eggs or juvenile in females was also recorded for each specimen.

Only sexed specimens were used in this study.

\section{Results}

A total of 669 crabs were captured over one year, which included 378 males and 291 females. Sizes ranged from 9.50 to $60.30 \mathrm{~mm}$ CW for males and from 11.80 to $50.10 \mathrm{~mm} \mathrm{CW}$ for females. The smallest ovigerous female found was $36.90 \mathrm{~mm}$ CW; however, the largest was $50.10 \mathrm{~mm} \mathrm{CW}$.

The histogram was divided into 12 size classes with an interval of $5 \mathrm{~mm} \mathrm{CW}$ (Figure 5). The obtained population sample presented an abnormal distribution (Shapiro-Wilks' $W=0.97, \quad P<0.05)$. Mean carapace width of males $28.98 \pm 10.78 \mathrm{~mm}$ was significantly larger than that of females $28.62 \pm 8.48 \mathrm{~mm},(t=2.47 ; P<0.05)$. Young crabs were the most dominant in the samples. In contrast, larger crabs were sporadically recorded throughout the study period (Table 1). A small number of ovigerous females were registered, in June $(N=2)$ and July $(N=1)$; however, females carrying hatched eggs (juveniles) in their abdomen were collected in September $(N=2)$.

The sex ratio of the total population was significantly different from $1: 1$ ratio $(P<0.05)$ (Table 2$)$.

During fieldwork, three matings were observed. The couples were found in the shallow water, and both partners had rigid exoskeletons. The male holds the female's second pereopods with the aid of his first pereopods (chelipeds), and then turning her over and pushing her under himself, at the same time inserting his abdomen under his partner. Males were larger than copulating females in all observed cases.

\section{Discussion}

In the present study, males were significantly larger than females. Analysis of the population structure showed that the size classes were unequally represented in the sexes. Specimens over 31 and under $26 \mathrm{~mm}$ CW were more often males, and this class coincides with the size at which the puberty ecdysis occurs [20], whereas females were represented mostly in the $26-30 \mathrm{~mm}$ CW range. Crab populations with larger males have already been noticed for Potamon fluviatile, Potamon potamios palestinensis, and Potamon gedrosianum $[13,18,21]$. This phenomenon may be associated with the increase of the intermolt interval [22, 23] and/or the decrease of the growth rate [24]. However, this is in contrast to what has been observed for other freshwater crabs, when the females were larger than males, as the cases of Dilocarcinus pagei and Trichodactylus fluviatilis [25, 26].

The reproductive activity could be also a second possible phenomenon limiting female size growth in Brachyura [27]. Moreover, both reproduction and molting involve important energy needs [28-31]. As in the case of $P$. fluviatile populations [4], reproduction and ecdysis periods of Potamon algeriense almost synchronize, it is improbable that the crab would undergo both phenomena in the same annual cycle.

The high cost of egg production resulting a higher mortality rate, (if we compare it with the low cost of spermatogenesis 


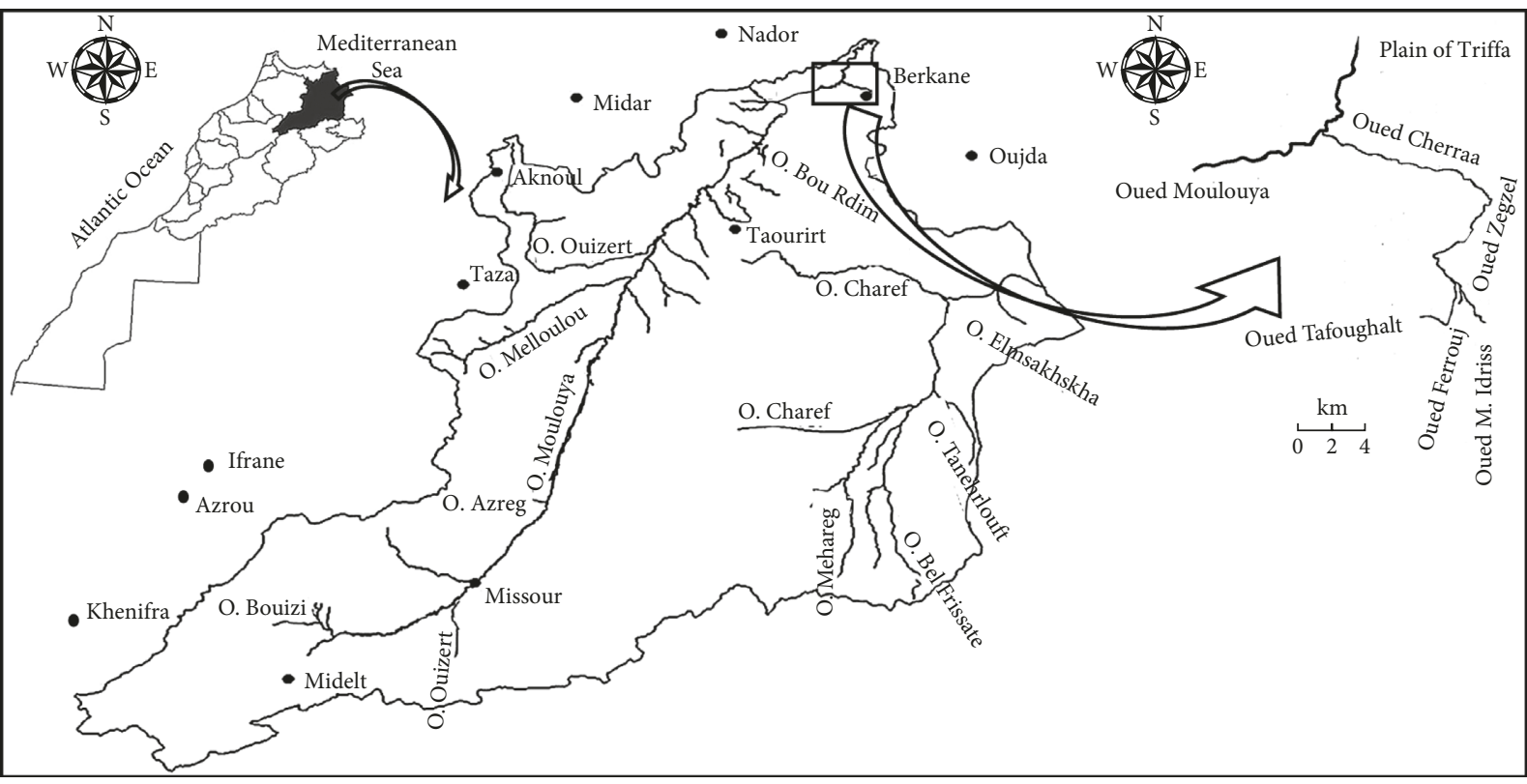

FIgURE 1: Localization of the study area, Oued Zegzel, Morocco.

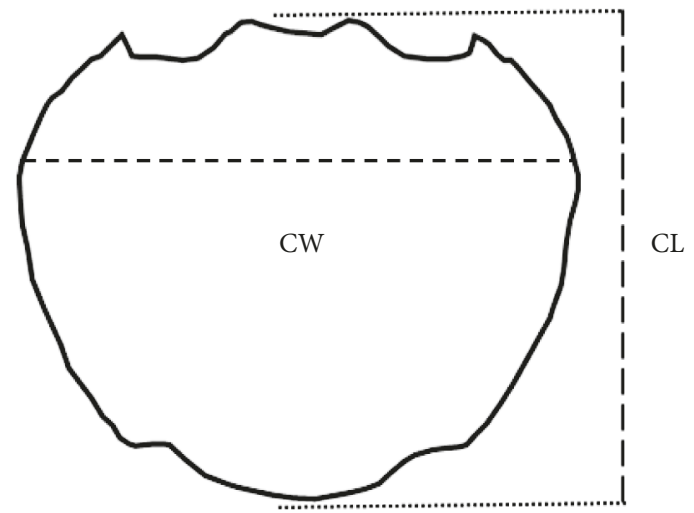

Figure 2: Position of carapace measurement in Potamon algeriense.

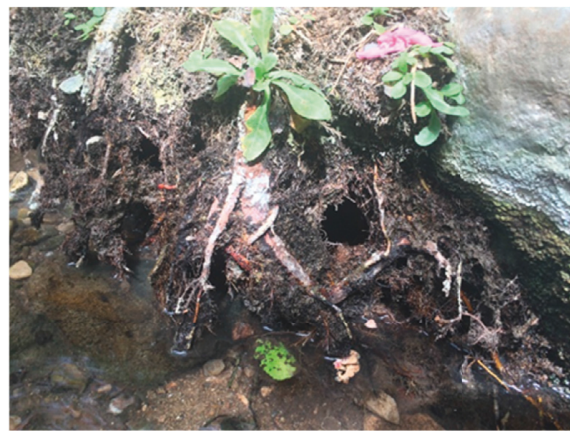

(a)

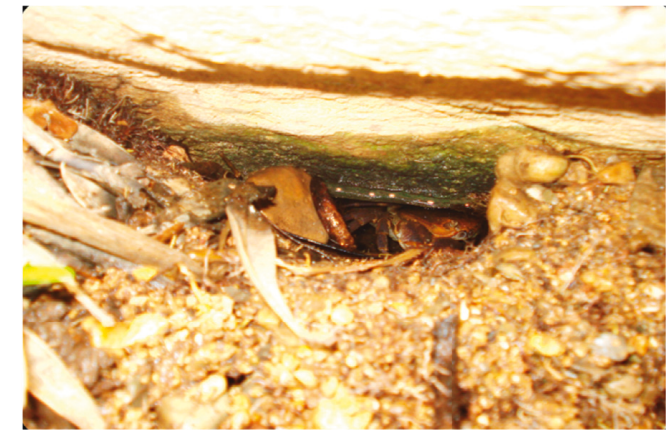

(b)

Figure 3: Habitat and burrows of the Potamon algeriense.

processes) [32], and/or by the intense vagility exhibited during the preovulatory period [2], could be a third possible explanation for the smaller size of females due to the exposure to many risks such as predation and dehydration.
Based on daytime sampling only, the population structure follows an apparent asymmetry, with small crabs $(\mathrm{CW}<26 \mathrm{~mm})$ being represented more than larger ones. These results are with the agreement of what has been 


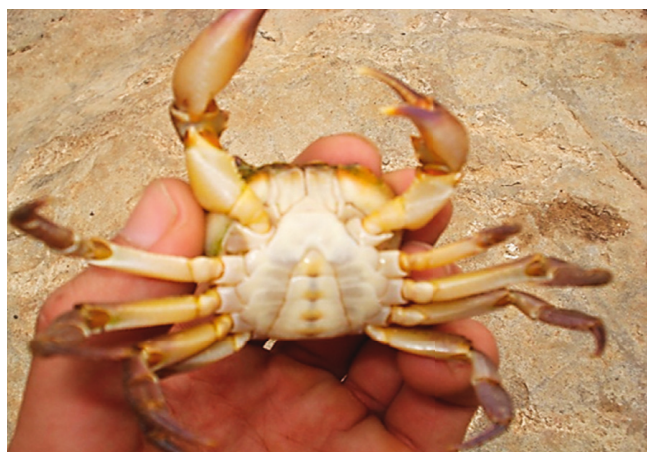

(a)

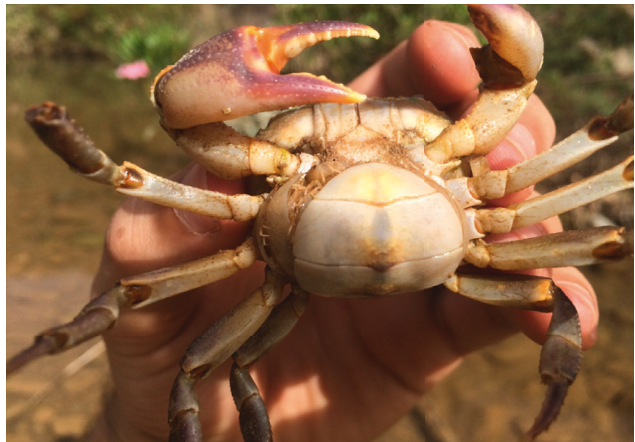

(b)

Figure 4: Abdomen morphology of the Potamon algeriense: (a) male abdomen and (b) female abdomen.

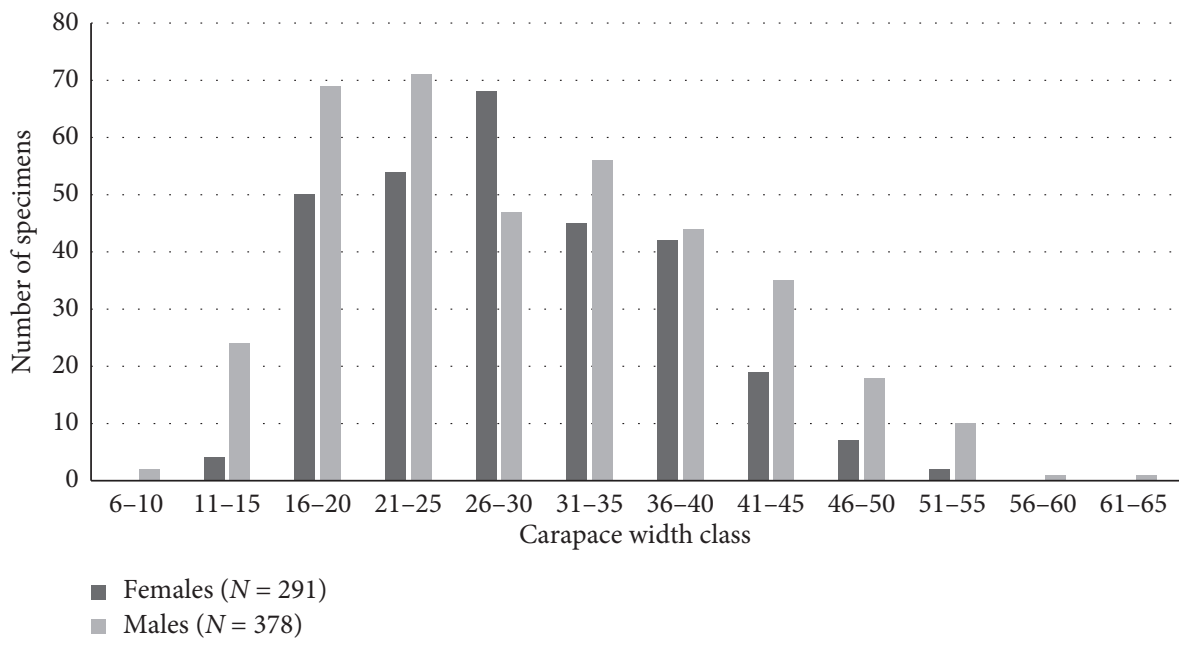

FIgURe 5: Size frequency distribution of the Potamon algeriense by sex and $5 \mathrm{~mm}$ carapace width interval.

TABle 1: Sex ratio by size class of Potamon algeriense from Oued Zegzel, Morocco, over one year period $(P<0.05)$.

\begin{tabular}{|c|c|c|c|c|c|c|c|c|}
\hline \multirow{2}{*}{ Size class } & \multicolumn{2}{|c|}{ Males } & \multicolumn{2}{|c|}{ Females } & \multirow{2}{*}{ Total } & \multirow{2}{*}{ Sex ratio } & \multirow{2}{*}{$P$} & \multirow{2}{*}{ Significance } \\
\hline & $\mathrm{N}$ & $\%$ & $\mathrm{~N}$ & $\%$ & & & & \\
\hline 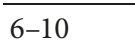 & 2 & 100.00 & 0 & 0.00 & 2 & - & $P>0.05$ & NS \\
\hline $11-15$ & 24 & 85.71 & 4 & 14.29 & 28 & $6: 1$ & $P<0.05$ & $\mathrm{~S}$ \\
\hline $16-20$ & 69 & 57.98 & 50 & 42.02 & 119 & $1.38: 1$ & $P>0.05$ & NS \\
\hline $21-25$ & 71 & 56.80 & 54 & 43.20 & 125 & $1.31: 1$ & $P>0.05$ & NS \\
\hline $26-30$ & 47 & 40.87 & 68 & 59.13 & 115 & $0.69: 1$ & $P>0.05$ & NS \\
\hline $31-35$ & 56 & 55.45 & 45 & 44.55 & 101 & $1.24: 1$ & $P>0.05$ & NS \\
\hline $36-40$ & 44 & 51.16 & 42 & 48.84 & 86 & $1.04: 1$ & $P>0.05$ & NS \\
\hline $41-45$ & 35 & 64.81 & 19 & 35.19 & 54 & $1.84: 1$ & $P<0.05$ & $S$ \\
\hline $46-50$ & 18 & 72.00 & 7 & 28.00 & 25 & $2.57: 1$ & $P<0.05$ & S \\
\hline $51-55$ & 10 & 83.33 & 2 & 16.67 & 12 & $5: 1$ & $P<0.05$ & S \\
\hline $56-60$ & 1 & 100.00 & 0 & 0.00 & 1 & - & $P>0.05$ & NS \\
\hline $61-65$ & 1 & 100.00 & 0 & 0.00 & 1 & - & $P>0.05$ & NS \\
\hline Total & 378 & 56.50 & 291 & 43.50 & 669 & $1.30: 1$ & $P<0.05$ & $\mathrm{~S}$ \\
\hline
\end{tabular}

observed in the cases of Potamon potamios palestinensis [18] and P. fluviatile [13]. This phenomenon could be explained by the cryptic behavior of adult individuals, especially during daytime hours, who tend to hide under stones and between aquatic plants, in order to avoid extreme temperatures, diurnal predators, and low humidity.
All these factors push the adult crabs to focus their activity at night. A nocturnal activity pattern has also been reported in the Italian freshwater crab P. fluviatile (except in the coldest months, where individuals are active during daytime) [3], in the P. gedrosianum of Afghanistan [21] and in the $P$. potamios palestinensis of Palestine [18]. In contrast, 
Table 2: Sex ratio by month of Potamon algeriense from Oued Zegzel, Morocco, over one year period $(P<0.05)$.

\begin{tabular}{|c|c|c|c|c|c|c|c|c|}
\hline \multirow{2}{*}{ Month } & \multicolumn{2}{|c|}{ Males } & \multicolumn{2}{|c|}{ Females } & \multirow{2}{*}{ Total } & \multirow{2}{*}{ Sex ratio } & \multirow{2}{*}{$P$} & \multirow{2}{*}{ Significance } \\
\hline & $\mathrm{N}$ & $\%$ & $\mathrm{~N}$ & $\%$ & & & & \\
\hline Oct & 38 & 54.29 & 32 & 45.71 & 70 & $1.19: 1$ & $P>0.05$ & NS \\
\hline Nov & 35 & 55.56 & 28 & 44.44 & 63 & $1.25: 1$ & $P>0.05$ & NS \\
\hline Dec & 42 & 59.15 & 29 & 40.85 & 71 & $1.45: 1$ & $P>0.05$ & NS \\
\hline Jan & 40 & 44.44 & 50 & 55.56 & 90 & $0.80: 1$ & $P>0.05$ & NS \\
\hline Feb & 5 & 41.67 & 7 & 58.33 & 12 & $0.71: 1$ & $P>0.05$ & NS \\
\hline Mar & 2 & 25.00 & 6 & 75.00 & 8 & $0.33: 1$ & $P>0.05$ & NS \\
\hline Apr & 25 & 58.14 & 18 & 41.86 & 43 & $1.39: 1$ & $P>0.05$ & NS \\
\hline May & 11 & 61.11 & 7 & 38.89 & 18 & $1.57: 1$ & $P>0.05$ & NS \\
\hline Jun & 48 & 62.34 & 29 & 37.66 & 77 & $1.66: 1$ & $P<0.05$ & $\mathrm{~S}$ \\
\hline Jul & 38 & 59.38 & 26 & 40.63 & 64 & $1.46: 1$ & $P>0.05$ & NS \\
\hline Aug & 46 & 56.79 & 35 & 43.21 & 81 & $1.31: 1$ & $P>0.05$ & NS \\
\hline Sep & 48 & 66.67 & 24 & 33.33 & 72 & $2.00: 1$ & $P<0.05$ & $S$ \\
\hline Total & 378 & 56.50 & 291 & 43.50 & 669 & $1.30: 1$ & $P<0.05$ & $S$ \\
\hline
\end{tabular}

S: significative; NS: nonsignificative.
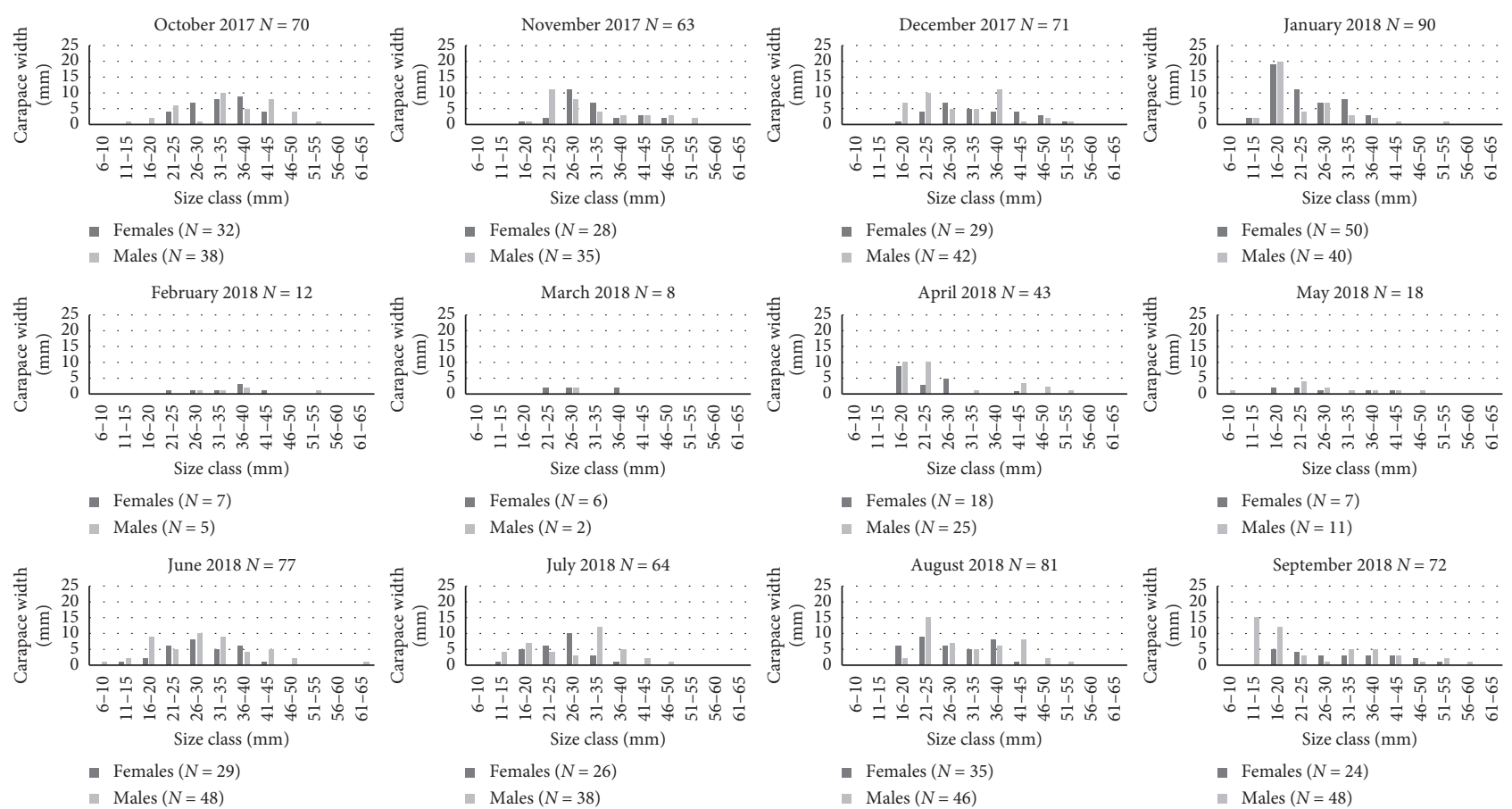

Figure 6: Monthly specimen's distributions of males and females by size class of Potamon algeriense from Oued Zegzel.

small crabs are more active in the daytime. In fact, the prevalence of diurnalism within the young specimens is probably the consequence of the intensive competition exerted on them by adults, who will even cannibalize small conspecifics, as observed in $P$. potamios palestinensis and $P$. fluviatile.

Fewer crabs were caught during the sampling period from February to May (Figure 6). This could be explained by the strong river flow due to the massive rainfall in the area of the study. In fact, the region is characterized by a Mediterranean climate, and those months are known by their heavy precipitations.

During the reproduction period (from May to October), the sex ratio changes. More males were found than females, especially in June and September, when females carry eggs under their abdomens. Consequently, their locomotor activity began to be cryptic and limited [3]. In fact, the inconspicuous behavior of mature females may explain the small number of ovigerous and juvenile-carrying females in the samples. An identical behavior has been reported for the freshwater crab Trichodactylus fluviatilis [26] and the terrestrial crab Geosesarma notophorum [33].

\section{Conclusion}

Certainly, more data are required concerning diet composition, phylogeography, parasitology, and the frequencies of spawning and molting to complete the lack of information about this unstudied species. 


\section{Data Availability}

All data used to support the findings of this study are available from the corresponding author upon request.

\section{Conflicts of Interest}

The authors declare no conflicts of interest regarding the use of research contents and publication of this paper.

\section{References}

[1] S. Daniels, B. A. Stewart, G. Gouws, M. Cunningham, and C. A. Matthee, "Phylogenetic relationships of the southern African freshwater crab fauna (Decapoda: Potamonautidae: Potamonautes) derived from multiple data sets reveal biogeographic patterning," Molecular Phylogenetics and Evolution, vol. 25, no. 3, pp. 511-523, 2002.

[2] F. Gherardi, F. Tarducci, and M. Vannini, "Locomotor activity in the freshwater crab Potamon fluviatile: the analysis of temporal patterns by radio-telemetry," Ethology, vol. 77, no. 4, pp. 300-316, 2010.

[3] F. Gherardi, G. Messana, A. Ugolini, and M. Vannini, "Studies on the locomotor activity of the freshwater crab, Potamon fluviatile," Hydrobiologia, vol. 169, no. 2, pp. 241-250, 1988.

[4] F. Micheli, F. Gherardi, and M. Vannini, "Growth and reproduction in the freshwater crab, Potamon fluviatile (Decapoda, Brachyura)," Freshwater Biology, vol. 23, no. 3, pp. 491-503, 1990.

[5] R. G. Hartnoll, "Evolution, systematics, and geographical distribution," in Biology of the Land Crabs, W. W. Burggren and B. R. McMahon, Eds., Cambridge University Press, Cambridge, UK, pp. 6-53, 1988.

[6] N. Cumberlidge, "The freshwater crabs of West Africa: family Potamonautidae," IRD Editions, vol. 36, p. 382, 1999.

[7] N. Cumberlidge, "Freshwater crabs and shrimps (Crustacea: Decapoda) of the nile basin," in The Nile Origin Environments Limnology and Human Use, H. J. Dumont, Ed., vol. 89Springer, Monographiae Biologicae, pp. 547-561, Springer, 2009.

[8] D. Brandis, V. Storch, and M. Türkay, "Taxonomy and zoogeography of the freshwater crabs of Europe, North Africa and the Middle East," Senckenberg Biology, vol. 2, pp. 5-56, 2000.

[9] M. S. S. F OBE, "38. Notes on freshwater crabs in Egypt, Sinai, and the Sudan," Proceedings of the Zoological Society of London, vol. 101, pp. 729-735, 1931.

[10] S. R. Reice and G. Herbst, "The rôle of salinity in decomposition of leaves of Phragmites australis in desert streams," Journal of Arid Environments, vol. 5, no. 4, pp. 361-368, 1982.

[11] N. Cumberlidge, Potamon Fluviatile. The IUCN Red List of Threatened Species, IUCN, Gland, Switzerland, 2008.

[12] R. Jesse, M. Pfenninger, S. Fratini, M. Scalici, B. Streit, and C. D. Schubart, "Disjunct distribution of the Mediterranean freshwater crab Potamon fluviatile-natural expansion or human introduction?," Biological Invasions, vol. 11, no. 10, pp. 2209-2221, 2009.

[13] F. Gherardi, S. Guidi, and M. Vannini, "Behavioral ecology of the freshwater crab. Potamon fluviatile: preliminary observations," Investigación Pesquera, vol. 51, pp. 389-402, 1987.

[14] N. Cumberlidge and S. R. Daniels, "A conservation assessment of the freshwater crabs of southern Africa (Brachyura: Potamonautidae)," African Journal of Ecology, vol. 46, no. 1, pp. 74-79, 2008.
[15] D. C. J. Yeo, P. K. L. Ng, N. Cumberlidge, C. Magalhaes, S. R. Daniels, and M. Campos, "Global diversity of crabs (Crustacea: Decapoda: Brachyura) in freshwater," in Freshwater Animal Diversity Assessment, vol. 198, pp. 275-286, Springer, Hydrobiologia, Springer, 2008.

[16] N. Cumberildge, "Potamon algeriense," The IUCN Red List of Threatened Species:e.T134365A3945207, 2008.

[17] F. Gherardi, F. Micheli, F. Monaci, and L. Tarducci, "Note sulla biologia ed ecologia del granchio di fiume. Potamon fluviatile," Bulletin du Museum national d'histoire naturelle Sciences, vol. 6, pp. 169-174, 1988.

[18] F. Gherardi and F. Micheli, "Relative growth and population structure of the freshwater crab. Potamon potamios palestinensis, in the dead Sea area (Israel)," Israel Journal of Zoology, vol. 136, pp. 133-145, 1989.

[19] F. Gherardi and M. Vannini, "Spatial behavior of the freshwater crab. Potamon fluviatile: a radio- telemetric study," Biological Behaviour, vol. 14, no. 28-45, 1989.

[20] S. Fadlaoui, M. Mahjoub, O. El Asri, and M. Melhaoui, "Allometric growth of the freshwater crab Potamon algeriense (Bott, 1967) (Decapoda, Brachyura, Potamidae) in oued Zegzel, a mountain stream, in the northeast of Morocco," International Journal of Zoology, vol. 2019, Article ID 5168639, 8 pages, 2019.

[21] P. Schneider, "Beiträge zur Biologie der afghanischen Flusskrabbe Potamon gedrosianum Alcock. 1910. III. Versuche zurn Aktivitätsverlauf," Bonner Zoologische Beitraege, vol. 25, pp. 297-305, 1974.

[22] R. W. Hiatt, "The biology of the lined shore crab, Pachvgrapsus crassipes Randall," Pacific Sciences, vol. 2, pp. 135-213, 1948.

[23] D. B. Bennet, "Growth of the edible crab (Cancer pagurus L.) of south-west England," Journal of the Marine Biological Association of the United Kingdom, vol. 54, no. 4, pp. 803-823, 1974.

[24] F. C. Cleaver, Preliminary Results of the Coastal Crab (Cancer magister) Investigation, pp. 47-82, State of Washington, Department of Fisheries, Washington, DC, USA, 1949.

[25] F. G. Taddei, "Biologia populacional e crescimento do caranguejo de agua doce Dilocarcinus pagei Stimpson. 1861 (Crustacea. Brachyura. Trichodactylidae) da represa municipal de Sao Jose do Rio Preto. SP,” Dissertar;ao (mestrado), Instituto de Biociencias, Universidade Estadual Paulista. Botucatu, Botucatu, Brazil, p. 107, 1999.

[26] D. T. Alarcon, M. H. A. De Leme, and V. J. Cobo, "Population structure of the freshwater crab Trichodactylus fluviatilis latreille, 1828 (Decapoda, Trichodactylidae) in Ubatuba, Northern Coast of São Paulo State, Brazil," in Modern Approaches to the Study of Crustacea, pp. 179-182, Springer, Berlin, Germany, 2002.

[27] R. G. Adiyodi, "Reproduction and its control," Integument, Pigments, and Hormonal Processes, vol. 8, pp. 147-215, 1985.

[28] L. M. Passano, "Molting and its control," The Physiology of Crustacea, vol. 1, pp. 473-536, Academic Press, Cambridge, MA, USA, 1960.

[29] T. Yamaguchi and Y. Takamatsu, "Ecological and morphological studies on the Japanese freshwater crab Geotelphusa dehaani," Journal of Biological Sciences, vol. 15, pp. 1-27, 1980.

[30] F. Gherardi, F. Tarduccl, and F. Micheli, "Energy maximization and foraging strategies in Potamon fluviatile (Decapoda, Brachyura)," Freshwater Biology, vol. 22, no. 2, pp. 233-245, 1989c.

[31] K. K. Pillay and N. B. Nair, "The annual reproductive cycles of Uca annulipes, Portunus pelagicus and Metapenaeus affinis 
(Decapoda: Crustacea), from the South-West coast of India," Marine Biology, vol. 11, pp. 152-166, 1971.

[32] M. F. Wilson and E. R. Pianka, "Sexual selection, sex ratio and mating system," The American Naturalist, vol. 97, pp. 405407, 1963.

[33] C. G. S. Tan and P. K. L. Ng, "Geosesarma notophorum sp. Nov. (Decapoda, Brachyura, Grapsidae, sesarminae), a terrestrial crab from sumatra, with novel brooding Behaviour," Crustaceana, vol. 68, no. 3, pp. 390-395, 1995. 

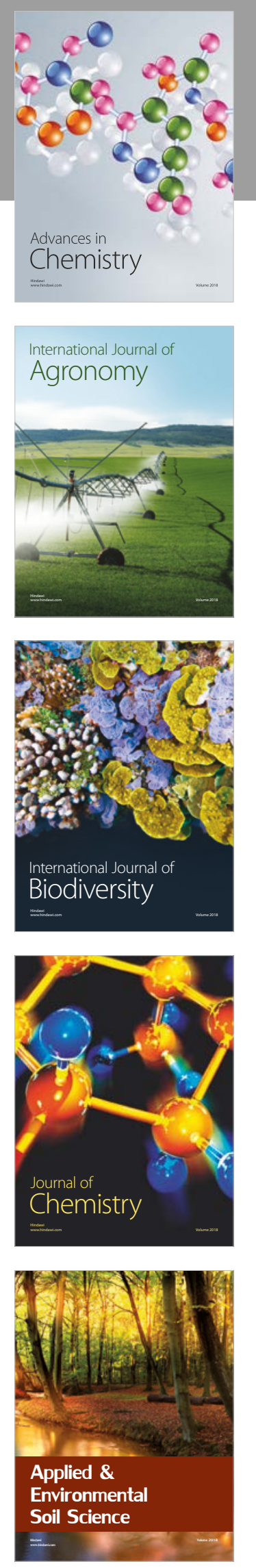

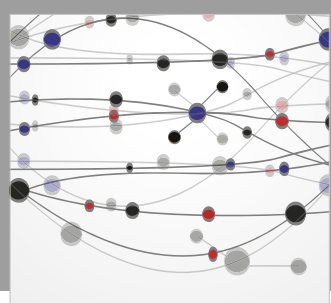

The Scientific World Journal

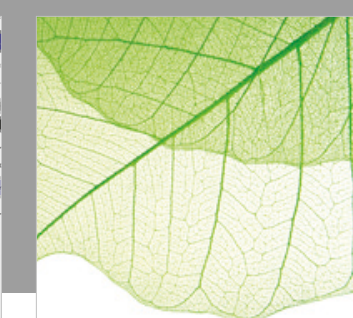

Journal of Botany

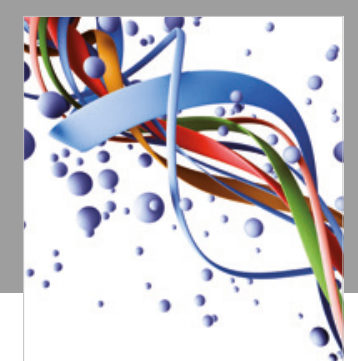

Scientifica

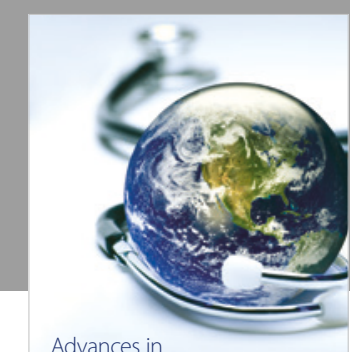

Public Health

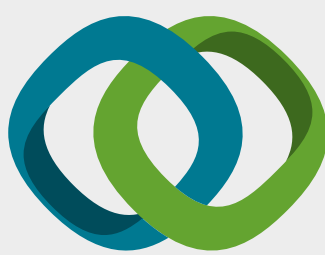

Hindawi

Submit your manuscripts at

www.hindawi.com
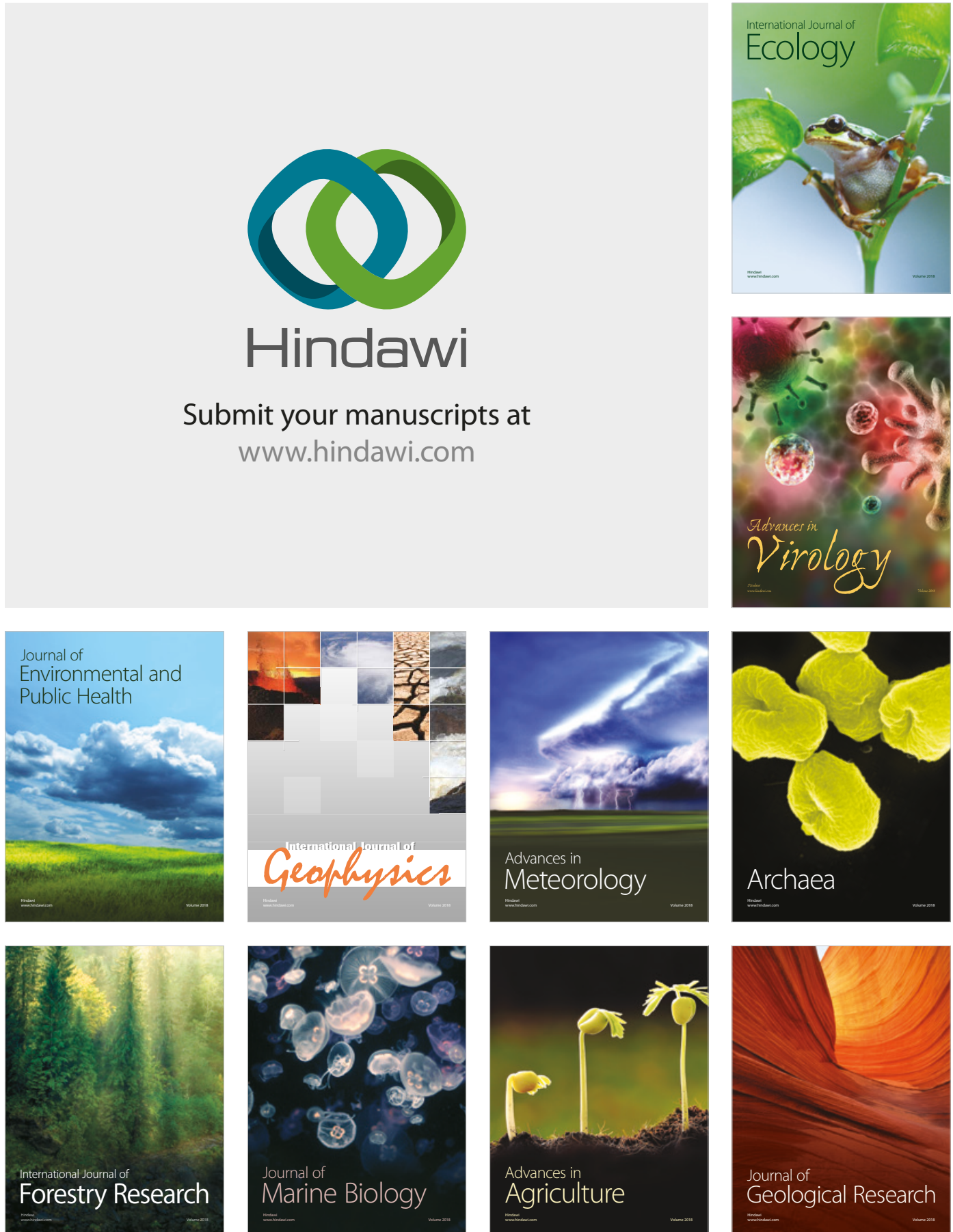

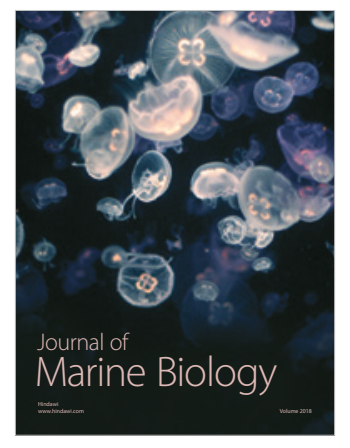

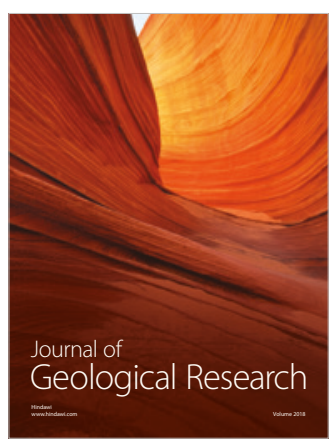

